\title{
Fernando Catroga
}

\section{Istorija, vreme i pamćenje}

\author{
Clio, Beograd, 2011., 334 str.
}

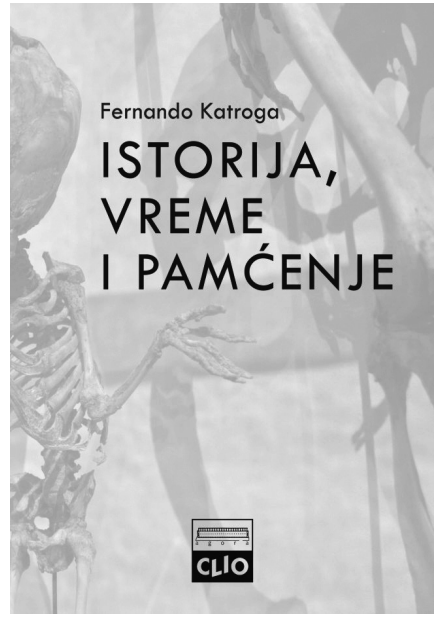

Knjiga Istorija, vreme $i$ pamćenje portugalskoga autora Fernanda Catroge sintetizira, kako sam autor navodi, rezultate njegovih dugogodišnjih istraživanja na području historiografije i filozofije povijesti. Čitajući knjigu i prolazeći kroz tekst posložen u četiri poglavlja - Poetika odsutnosti, Posrednici i posredovanje, Aktivno čekanje nade i Ono čega još nema - čitatelj može uvidjeti kako u tekstu ne postoji posve sustavan i strogo strukturiran tijek misli koji bi se mogao pratiti od prve do posljednje stranice, što proizlazi upravo iz sintetskoga, gotovo zborničkoga karaktera knjige. Paolo Archer u pogovoru ističe Catroginu veliku zaslugu za razvoj historiografije u Portugalu i zemljama luzitanskoga govornog područja. Ova knjiga predstavlja još jedan prilog toj zadaći.

Catroga u predgovoru za srpsko izdanje knjige piše kako je se može čitati i kao neku vrstu otvorenoga djela „zbog odbrane kraja kraja istorije i zbog prihvatanja postojanja dokle god je ontološko i narativno stanje čoveka. Zato čovek može biti prihvaćen kao istorijsko biće, odnosno kao čvor neprestanog vezivanja iskustva o sebi i o svetu s linijom koja, bezimena kao bezlični san, njegov život skicira kao projekat(e). Jer kako je konačnost njegova sigurna sudbina - smrt je uvek odloženo prevazilaženje horizonta - tako je historija, zametak znaka, materijalni garant i poslednje uporište traganja za smislom postojanja." (str. 11). Čovjek je povijesno biće, biće povijesti, ali istovremeno i biće otvoreno budućnosti. Vodeći neprestani dijalog s prošlošću čovjek otkriva svoju anamnetičnu narav, što znači da se povezuje s vlastitom prošlosti gradeći na njoj temelj osobnoga identiteta. Odnos prema prošlosti nije uvijek identičan i ovisi iz koje će perspektive subjekt djelovati, odnosno hoće li biti usmjeren na tematizaciju kolektivnoga ili osobnog pamćenja ${ }^{1}$ (ili autobiografskog i historijskog, kako piše Catroga). Sjećanja su najčešće subjektivna, osobna, „iako svako ja dobija svest o sebi samo kroz opštenje s drugima, zbog čega evociranje onoga što mu je svojstveno podstiče uslove koji ga socijalizuju“ (str. 18) jer se,

1 Catroga u knjizi ne naznačuje strogu razliku između pamćenja i sjećanja, tako da se oni i u ovome tekstu koriste kao sinonimi. 
reći će Maurice Halbwachs, čovjek obrazuje unutar kolektivnih/društvenih modela sjećanja. Catroga sjećanje određuje kao „predstavljanje (ili vraćanje prisutnosti) prošlog vremena“ (str. 18). Ako se zanemari sjećanje ili pamćenje, može li se uopće govoriti o historiografiji? Svakako da ne. Međutim historiografija nije ni nekritično nizanje događaja budući da je njezin značaj u tome što čovjeku pomaže razumjeti sadašnjost, ali i promijeniti budućnost.

Sjećanje je uvijek selektivno, tako da je čovjekov odnos prema prošlosti obilježen dijalektičkim hodom između sjećanja i zaborava, upamćenoga i zaboravljenog. „Zbog svega toga“, piše Catroga, „mora se prihvatiti da pamćenje i zaborav zahtevaju jedno drugo." (str. 26). Čovjekovo sjećanje također nije ni krajnje objektivno jer se rijetko kada radi o pukom (bezinteresnom) prizivanju prošlosti. Češće je prisutnija želja, kako ističe Walter Benjamin, da se tu prošlost transformira, odnosno prilagodi potrebama onoga subjekta koji se sjeća. „Takođe je poznato da pamćenje (pojedinačno i/ili kolektivno) ima tendenciju da ne zapamti zaboravljeno koje stvara, kao i da ne prihvati da je jedna vrsta vrha ledenog brega onoga što je podsvesno ili nesvesto." (str. 28). Osim sjećanja shvaćenoga u smislu čiste misaone konstrukcije, ono može biti i materijalizirano u obliku spomenika. Spomenik je vrsta oživljenoga sjećanja koje se dijeli s drugima. Njegovom materijalizacijom društvo teže dolazi u stanje mnemotropizma. Kao i mnogi drugi autori, Catroga smatra da je jedan od velikih problema suvremenih društva mnemotropizam, odnosno nesvjesna sklonost izmjenjivanju pojedinačnoga ili kolektivnog pamćenja. Bez ispravnoga pamćenja pojedinac nema ni adekvatne svijesti o sebi jer ,jedino Mnemosina, boginja pamćenja, može povezati ono što smo bili, ono što jesmo i ono što ćemo biti; oni bez sjećanja, ili s potpunom anamnezom [...] nikada neće moći da znaju za sebe“ (str. 41).

Autor mnogo pažnje posvećuje problemima historiografije. Za razliku od osobnoga pamćenja koje „sakralizira“ sjećanje, historiografija nastoji biti kritička operacija koja će sa sjećanja ukloniti i najmanji oblik tajnovitosti. Pisanje je povijesti, dakle objektivna radnja kojom povjesničari žele bez predrasuda bilježiti povijesnu istinu obavljajući time čin „sahrane“ pamćenja. Historiografija je u tome smislu i bijeg od zapadanja u melankoliju. „Ako je, u izvesnom smislu, grobnica kao mesto sahrane bila prvi 'spomenik' ostavljen onima koji dolaze, pisana historija je takođe sredstvo kojim se vodi borba protiv zaborava, a time i protiv propadanja koje označava iter vremena." (str. 49). Ostaje, međutim, otvoreno pitanje u kojoj je mjeri historiografija doista borba protiv zaborava jer je i ona selektivna. Nadalje, interpretacija se povijesti uvijek tumači iz konkretnoga „sada“, odnosno iz pozicije a posteriori u koju je upleten sam povjesničar, pa ni tumačenja istih povijesnih događaja ne moraju (i ponekad nisu) identična u različitim vremenskim razdobljima. Koliko je sjećanje uopće objektivno? Može li svjedok uvijek biti objektivan promatrač? U kojoj je mjeri svjedok upoznat s uzrocima i razlozima povijesnih događaja? A u kojoj mjeri pak povjesničar? Sve su to pitanja koja povjesničar ne može zaobići. Ne zaobilazi ih ni Catroga. On smatra kako je nesumnjivo da se naše „sećanje hrani naivnom epistemologijom u kojoj se još lakše meša predstavljanje (koje uvek znači reprezentifikaciju) s realnom prošlošću, odnosno s passeidade, jednom vrstom magičnog efekta u kome reč biću daje ono što ono više nije. I ako se po ovom svojstvu razlikuje od estetske imaginacije, treba podsetiti da se i jedna i druga odnose na 'odsutni predmet'. "Odmah dodaje: 
„Međutim, ako estetska imaginacija može da ima, ili nema referencu, čin sećanja se (kao i istorijsko istraživanje) ne odriče prizivanja principa stvarnosti. To zahteva da njegove retrospektive, i pored toga što se poklapaju s prošlim (prethodnim) vremenom, polažu pravo na verovatnost, s ciljem da garantuju tačnost onoga što se priča, iako mu je jedino jemstvo, zbog nedostatka svedoka, zakletva samog prizivača prošlosti [...]“ (str. 52). No u kojoj mjeri vjerodostojnost te zakletve može biti narušena ideološkom pozicijom samoga kazivača-povjesničara? Nije li povijest većim dijelom konstrukt čovjekovih predodžbi o prošlim događajima nego samih sjećanja i dokumenata: „Prije osam godina znamenita novinarka i urednica Die Zeita, Marion Gräfin Dönhoff, pisala je o tome kako činjenice nemaju nikakvu ulogu u povijesti; odlučujuće su predodžbe koje ljudi o njima imaju." (Horvat Pintarić, 2009.:13). Historiografija ne staje na nizanju događaja i suhom bilježenju činjenica. Uvijek se radi o probiranju iz mnoštva materijala, suđenju o izabranome materijalu i slično. Catroga stoga vješto historiografiju određuje kao umijeće, ars memoriae: „Istoriografija je, sa svojim izborima i zaboravima, takođe stvorila (i stvara) 'fabrikat' pamćenja i, kroz svoju narativnu prirodu i svoje suučesništvo, direktno ili indirektno, sa obrazovnim sistemom, doprinela da se izbrišu ili omalovaže prethodna pamćenja, kao i da se ponovno uspostave, socijalizuju i duhovno preuzmu nova pamćenja." (str. 60 - 61).

Historiografija kao umijeće, odnosno historiografija kao znanstvena disciplina humanističke provenijencije kroz povijest je doživjela brojne promjene. Osobito je važnu promjenu donijela tzv. nova historiografija koju su širili autori okupljeni oko francuskoga časopisa Analles na čelu s Marcom Blochom i Lucienom Febvreom. Osnovna je pozicija „škole Anala“ bila utemeljena na pobuni protiv Rankeova pozitivističkoga modela iz devetnaestoga stoljeća i događajne povijesti (l’histoire événementielle). Uspostavlja se, nadalje, interdisciplinaran pristup te se širi opseg historiografskoga zanimanja, što se vidi iz podnaslova časopisa Analles koji glasi Économie, Société, Civilisation. Time dolazi do promjene fokusa, ali i revizije ranije uspostavljenoga kanona. S Carlom Ginzburgom i Giovannijem Levijem javlja se u talijanskoj historiografiji model tzv. mikrohistorije, što je bio najkonkretniji pokušaj da se „istoriografsko pripovedanje naseli konkretnim ljudima“ (str. 119). Izmijenjeni je temelj historiografije sada umanjio važnost filozofije u istraživanju, što Catroga ipak smatra problematičnim budući da se odbacivanjem filozofskoga stava „istraživanje prošlosti zasniva samo na fetišu dokumenata i fetišu metode, i kao da su njeni zaključci mimesis (oponašanje) stvarnosti ili puka racionalizacija zdravog razuma“ (str. 123). Iako se može reći da je historiografija osuđena na dokumente, ona ne postoji dok se dokumenti i ostala arhivska građa ne istraže i dok ih se kritički ne obradi, što u najmanju ruku pretpostavlja vrlo savjestan epistemološki pristup. S druge se pak strane može čitati i Nietzscheov zahtjev za „živom povijesti“, onom koja je sposobna (ali i obvezna) voditi dijalog između onoga što se zbilo i sadašnjosti: „Svakako mi trebamo historiju, no trebamo je drugačije no što je treba razmaženi dokoličar u vrtu znanja [...]. To znači da je trebamo za život i djelo, a ne za lagodno odvraćanje od života i djela, ili čak za uljepšavanje sebičnog života, te kukavičkog i lošeg djela. Historiji želimo služiti dok ona služi životu." (Nietzsche, 2004.:5).

Catroga u knjizi opsežan prostor daje i pitanju vremena zadržavajući se pri tome na zapadnjačkome, točnije linearnom modelu. U linearni je koncept vremena, koji je 
posve u duhu judeokršćanske tradicije, implicitno uključena svrhovitost povijesnoga kretanja prema krajnjoj točki simboliziranoj u eshatonu kao svojevrsnom kraju povijesti. No, kako piše Catroga, „da bi historija išla ka konačnom cilju (Endzweck), taj cilj nikad nije zamišljen kao ontološki kraj, pojam koji je zaslužio Kantovu ironiju u eseju Das Ende aller Dinge (Kraj svih stvari, 1795), jer bi to sprečilo transcendentalizam, ili bolje rečeno, pretpostavku same etičnosti ljudskog života“ (str. 190 - 191). Autor ne nudi rješenje te problematike, što u ovome slučaju nije ni nužno, ali na samome kraju knjige iznosi tezu da je proklamirani kraj povijesti, kakav se u različitim oblicima može naći kod Hegela, Alexandera Kojèvea ili Francisa Fukuyame, završio te da je došao „kraj kraja istorije“ (str. 281). Catroga do takvoga zaključka dolazi primjenjujući na historiografiju također model linearnoga i pravocrtnog kretanja vremena, koje unutar povijesnih znanosti jest dominantno. Zapadnjački pristup povijesti, a identično je i na području historiografije, počiva na modelu linearnoga vremena sa sviješću o konačnoj svrsi povijesti: „istorija je postavljena na scenu u skladu s dramaturgijom u kojoj je tragedija postavljena u službi srećnog završetka. Može se čak i podržati da njen zaplet simbolizuje Hristovu strast, koja se neprestano nastavlja, do konačne predaje." (str. 271).

Knjiga Istorija, vreme $i$ pamćenje otvara brojne teme te Fernando Catroga u njoj na gotovo tristotinjak stranica raspravlja o nekim od osnovnih problema povijesti i povijesnih znanosti. U kritičkome dijalogu s brojnim citiranim autorima daje širok pregled različitih mišljenja o određenim tematskim okvirima obrađenima unutar knjige, što čitatelju ponekad otežava uočiti autorov stav koji je najjasnije formuliran u proglašenju kraja kraja povijesti. Ovaj Catrogin tekst, međutim, nudi obilje materijala za ozbiljnije promišljanje povijesti i historiografije, što ga čini važnom karikom u pokušaju kritičkoga promišljanja povijesnih znanosti kao i onih znanosti koje su s njima povezane.

\section{Literatura:}

1. Catroga, F. (2011). Istorija, vreme i pamćenje. Beograd: Clio.

2. Horvat Pintarić, V. (2009). Tradicija i moderna. Zagreb: Gliptoteka HAZU.

3. Nietzsche F. (2004). O koristi i štetnosti historije za život. Zagreb: Matica hrvatska 